\title{
Analysis on Bacterial Community Structure of Groundwater in
}

\section{Changzhou City}

\author{
Chenyu Liu', a, Jihua Wang ${ }^{1, ~ b}$, Jianfei Guan ${ }^{1}$, Yao Ji ${ }^{1}$, Haichao Sui ${ }^{1}$ \\ ${ }^{1}$ College of Life Science and Technology, Harbin Normal University, 150025, China \\ a1521500125@qq.com, bwangjihua333@hotmail.com
}

Keywords: Groundwater, Bacterial community structure, Water quality, Correlations

Abstract. The groundwater was monthly sampled from two underground wells of wastewater treatment plant in Changzhou City during March 2016 to February 2017 to monitor groundwater quality and cultivated bacterial community in water. This study aims at analyzing bacterial community structure shift along with environmental variations. The results showed that the bacterial community structure and its shifts corresponding to different water quality. The number of bacteria in D1 and D2 were significantly different with the seasons. A total of 36 genera were profiled in two wells, the most dominant species was Paracoccus sp. (averagely accounting for $21.62 \%)$. However, 4 genera were detected as the most dominant bacteria in D1, whose dominance was $12 \%$, respectively. The RDA analysis showed that $\mathrm{NO}_{3}{ }^{-}$had a positive effect on Pseudomona sp. and Paracoccus sp. Positive correlations were found between Staphylococcus sp. and $\mathrm{NO}_{2}$. Methylococcus sp. and Acinetobacter sp. had positive correlations with TN. On the contrary, Aeromonas sp., Zoogloea sp., Shigella sp., Flavobacterium sp. and Deinococcus sp. had negetive correlations with $\mathrm{NH}_{3}-\mathrm{N}$.

\section{Introduction}

Changzhou City is located in the center of Yangtze River Delta [1]. The domestic sewage through the sewage treatment plant to meet the standards after discharge to the sewage channel in the city. The surface water will have a certain impact on water quality, and then it can affect the water quality of groundwater through infiltration and leakage. The water resources are far from meeting the water consumption. So the monitor of water quality is important [2].

There are a lot of bacteria in the water [3]. They play an important role in the material circulation and energy flow of aquatic ecosystems, and their species and quantity can be an important indicator of water quality evaluation [4-6]. In China, Jiang et al. [7] analyzed the water quality through the number and diversity of bacteria in the suburbs of Shanghai. Kaecska et al. [8] monitored bacterial community structure in the tail water of sewage treatment plants to analyze water quality changes in foreign country. In this study, groundwater samples were collected from March 2016 to February 2017 in sewage treatment plant of Changzhou City. It is expected to provide fundamental information for the monitor, evaluate and control of water quality [9].

\section{Materials and methods}

Experimental material. The groundwater were sampled from two underground wells (30 m depth) of a sewage treatment plant in Changzhou City of Jiangsu Province from March 2016 to February 2017. The water were collected on-site every month by the sterile container harvesting D1 and D2 under 5 to $8 \mathrm{~m}$ of water surface by mixing. All samples were divided into two parts and transferred 
to the laboratory. One of them used for water quality analysis within $24 \mathrm{~h}$, and the others had saved in $4^{\circ} \mathrm{C}$ and used for cultivated bacterial community structure analysis.

The samples was monthly sampled from March 2016 to February 2017. The spring lasts from March 2016 to May 2016, the summer lasts from June 2016 to August 2016, the autumn lasts from September 2016 to November 2016, the winter include December 2016, January 2017 and February 2017.

Water quality analysis. Water quality analysis parameters, for instance, total nitrogen (TN), ammonia nitrogen $\left(\mathrm{NH}_{3}-\mathrm{N}\right)$, nitrate nitrogen $\left(\mathrm{NO}_{3}{ }^{-}\right)$, nitrite nitrogen $\left(\mathrm{NO}_{2}{ }^{-}\right)$were measured according to the Standard Methods.

Cultivated bacterial counting. Samples were through filter membrane by equipment of vacuum filtration and incubated on the Luria-Bertani Solid Medium, and then counted and presented the number of colonies as numbers per milliliter solution.

Identified the bacterial genera. The bacteria were isolated, purified, physiological-biochemical experiments. Finally, The identification of bacterial genera referenced to the "Bergey's Manual of Systematic Bacteriology (eighth edition)".

Data analysis. All statistics of the data were arranged by Excel 2007. The bacteria counts and cultivable bacterial community structure were analyzed by Origin 8 . The relationship between bacterial community structure and water quality was analyzed by Canoco 5.0.

\section{Results and analysis}

Bacterial counts analysis. Cultivable bacterial counts for 12 months at two underground wells (D1, D2) were calculated by Origin 8. It can be seen from Fig.1 that the total number of cultivable bacteria in D1 and D2 showed a trend of increased first and then decreased, and it indicated that the number of cultivable bacteria at different sites in four seasons. The cultivable bacterial counts reached the highest point in September 2016 and July 2016, respectively. The values were 33.6× $10^{4}$ $\mathrm{CFU} / \mathrm{mL}$ and $38.7 \times 10^{4} \mathrm{CFU} / \mathrm{mL}$ in D1 and D2, respectively. The lowest point in January 2017 and December 2016, respectively, the values were $13.9 \times 10^{4} \mathrm{CFU} / \mathrm{mL}$ and $13.8 \times 10^{4} \mathrm{CFU} / \mathrm{mL}$, respectively. Compared with bacterial counts in D1 and D2, the change of D1 point was smaller than D2.

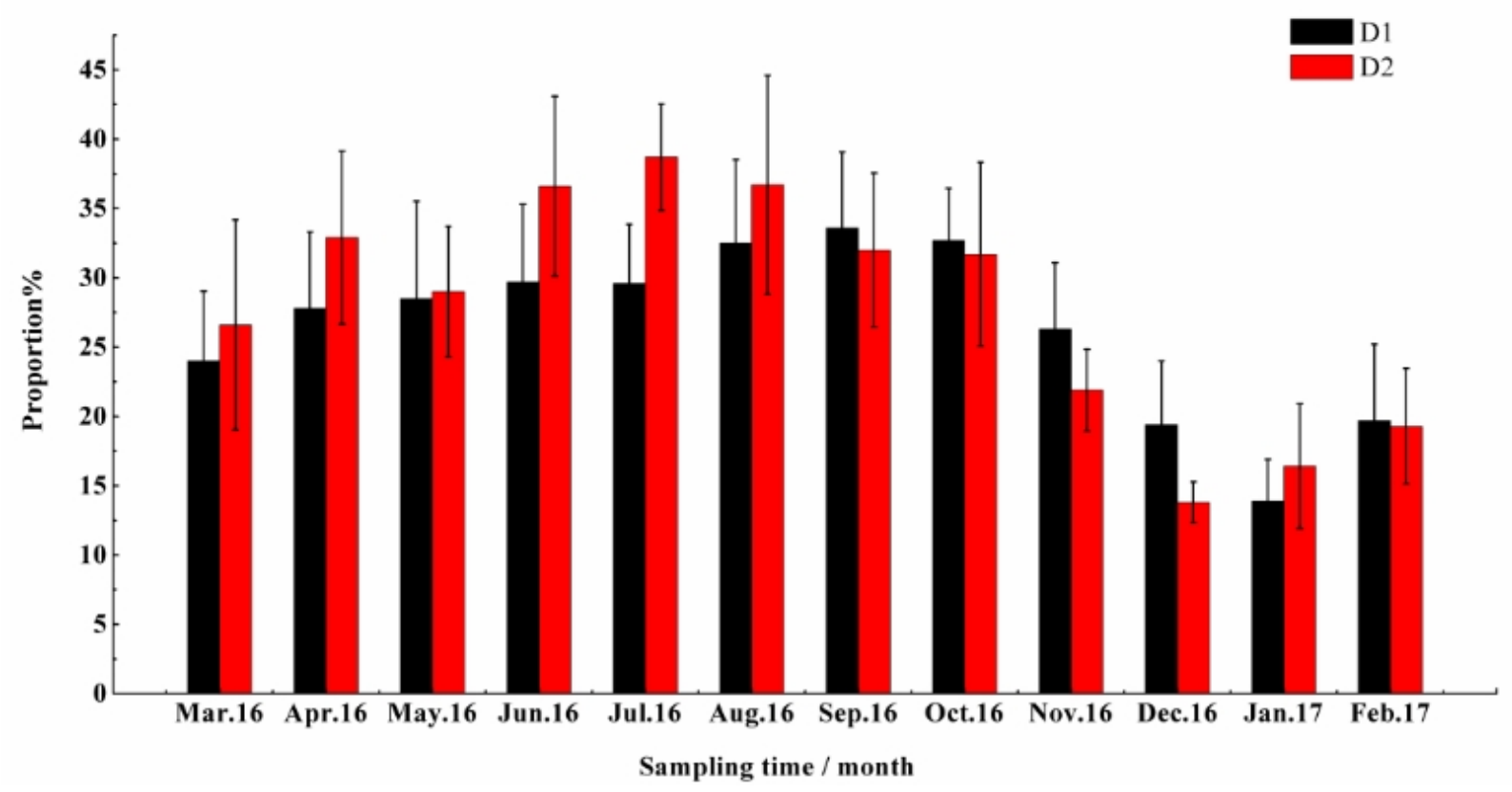

Fig.1 Quantitative map of groundwater bacteria 
Cultivable bacterial genera analysis. The cultivable bacteria were screened, separated, purified and identified at D1 and D2 in four seasons. 36 different genera were selected. As shown in Fig.2 and Fig.3, the results showed that Pseudomona sp., Azatobacter sp. and Xanthobacter sp. were the common genera in two sample sites. The analyze showed that Pseudomona sp., Azatobacter sp., Flavobacterium sp. and Xanthomonas $s p$. were the most dominant bacteria in D1. The degree were $12 \%$, respectively. The most dominant bacteria was Paracoccus sp. in D2, The degree was $21.62 \%$. It can be seen that the dominance of D2 was more obvious and more concentrated than D1. Aerococcus sp., Rahnella sp., Klebsiella sp., Exiguobacterium sp., Ochrobactrum sp., Acidomonas $s p$., Arthrobacter $s p$. and Aeromicrobium sp. were specific bacteria in D1. Neisseria sp., Methylococcus sp., and Halobacterium sp. were specific bacteria in D2.

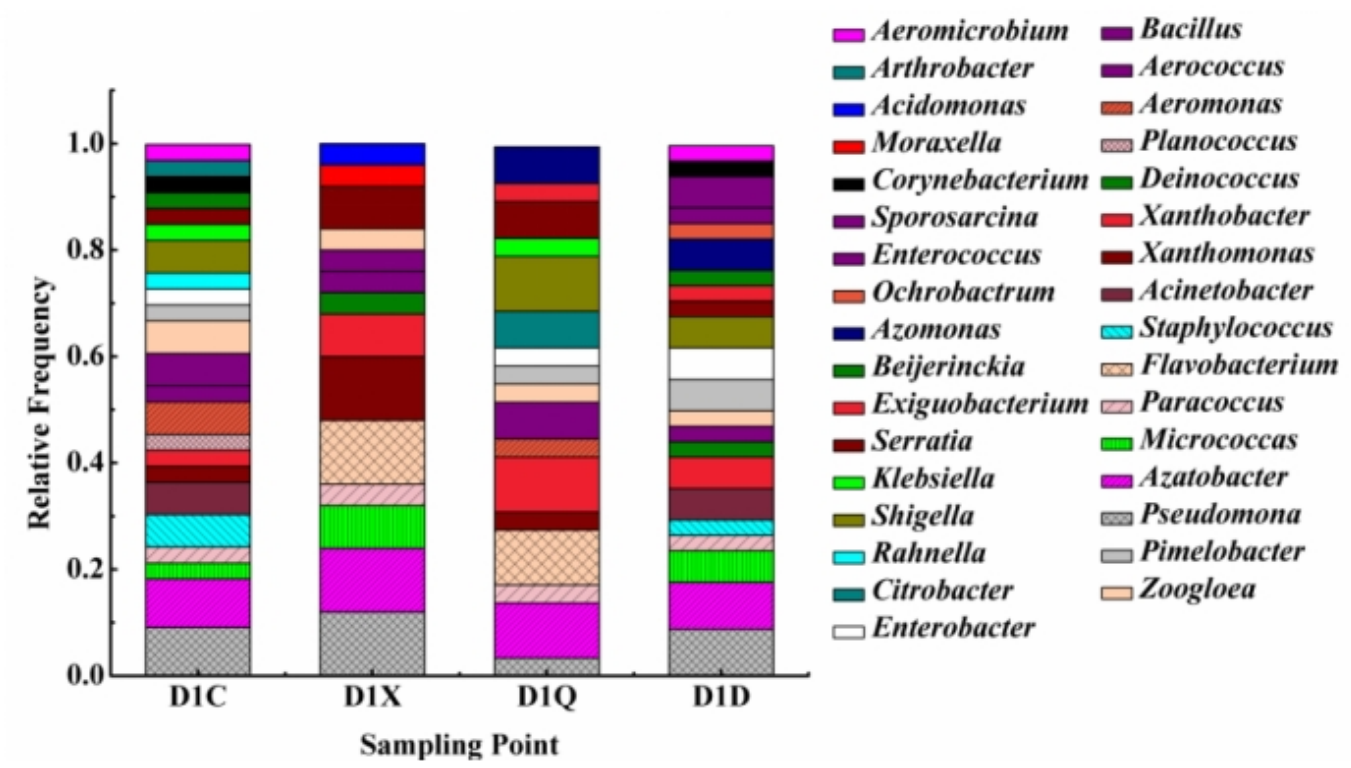

Fig.2 The proportion of bacteria by different seasons in D1

D1: Groundwater sampling point 1, C: spring, X: summer, Q: autumn, D: winlter.

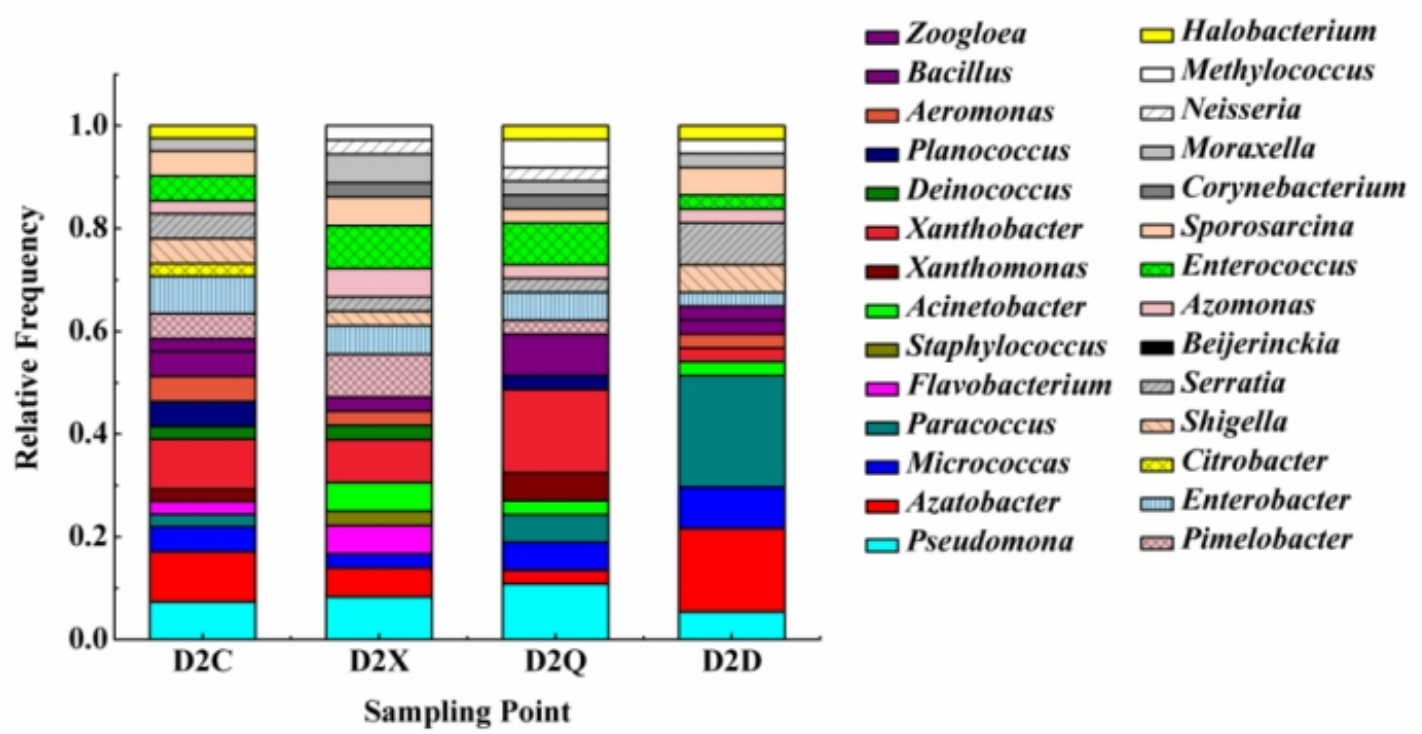

Fig.3 The proportion of bacteria by different seasons in D2

D2: Groundwater sampling point 2, C: spring, X: summer, Q: autumn, D: winter.

Correspondence between bacterial community and water quality analysis. Only RDA analysis of D2 was shown because it owned higher dominant bacteria compared with D1. As shown in Table 1, The eigenvalues of axes 1 and axes 2 were 0.3805 and 0.3333 , respectively, and the 
correlation between genera and environmental factors was 1.0000. Therefore, axes 1 and axes 2 of the sequencing map could be a real response to the impact of water quality on the bacterial community structure.

Table 1 The correlation values of the eigenvalues and species with water quality were analyzed by RDA analysis

\begin{tabular}{|c|c|c|c|c|c|}
\hline Project & Axis 1 & Axis 2 & Axis 3 & Axis 4 & $\begin{array}{l}\text { The total } \\
\text { of inertia }\end{array}$ \\
\hline Characteristic value & 0.3805 & 0.3333 & 0.2862 & 0.0000 & \\
\hline $\begin{array}{l}\text { Correlation between species } \\
\text { and water quality indicators }\end{array}$ & 1.0000 & 1.0000 & 1.0000 & 1.0000 & \\
\hline $\begin{array}{l}\text { Percentage change in } \\
\text { cumulative species data }\end{array}$ & 38.05 & 71.38 & 100.00 & 0.0000 & \\
\hline $\begin{array}{c}\text { The percentage of species and } \\
\text { environmental factor data } \\
\text { Cumulative Change }\end{array}$ & 38.05 & 71.38 & 100.00 & 0.0000 & \\
\hline The sum of the eigenvalues & & & & & 1.0000 \\
\hline The sum of typical eigenvalue & & & & & 1.0000 \\
\hline
\end{tabular}

The relationship between the cultivable bacterial community structure and the water quality in the different season was shown in Fig.4. The red arrows indicated water quality, the length of the arrows indicated the correlation between the bacterial community and the water quality. The angle between the arrow of genera and environmental factors indicated their correlations [10]. Table 4 showed the relationship between the bacterial community and water quality. $\mathrm{NO}_{3}{ }^{-}$had a positive effect on Pseudomona sp. and Paracoccus sp.. Positive correlations were found between Staphylococcus sp. and $\mathrm{NO}_{2}^{-}$. Methylococcus sp. and Acinetobacter sp. had positive correlations with TN. However, Aeromonas sp., Zoogloea sp., Shigella sp., Flavobacterium sp. and Deinococcus sp. had negetive correlations with $\mathrm{NH}_{3}-\mathrm{N}$.

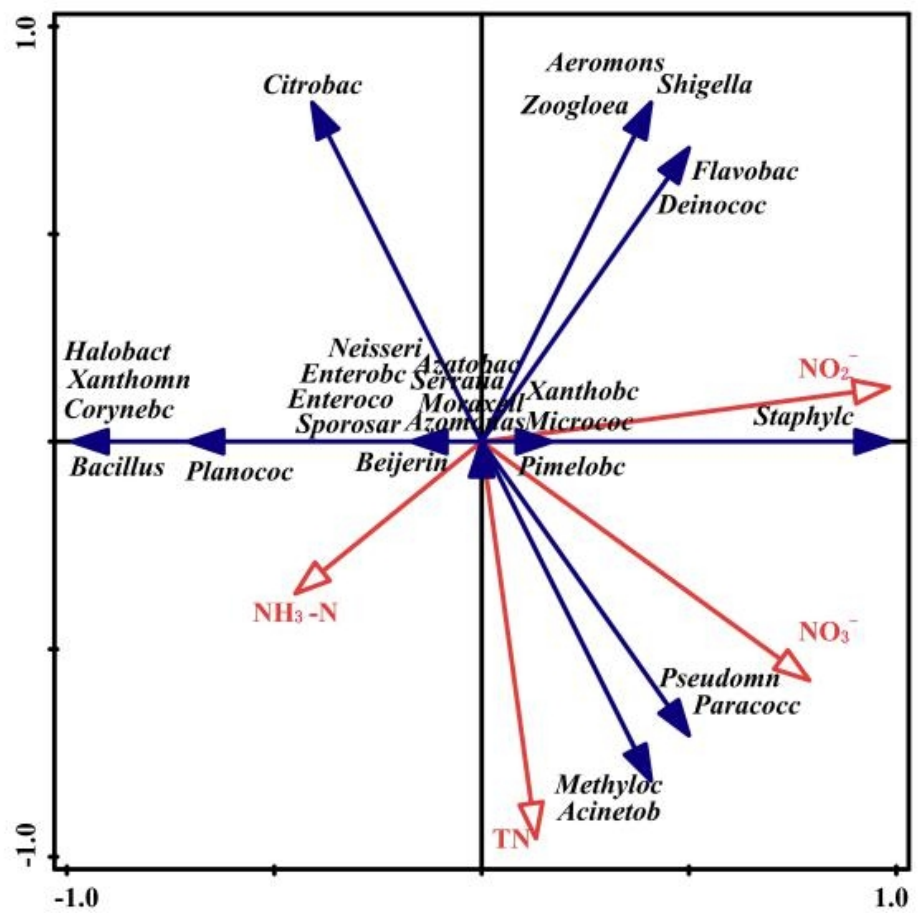

Fig.4 RDA analysis of the relationship between bacterial community structure and water quality $\mathrm{NO}_{2}^{-}$: Nitrite nitrogen, $\mathrm{NO}_{3}^{-}$: Nitrate nitrogen, TN: Total nitrogen, $\mathrm{NH}_{3}-\mathrm{N}$ : Ammonia nitrogen 


\section{Discussion}

A total of samples were collected from two underground wells. Monitored water quality and bacterial community structure, analyzed the relationship between bacterial community structure and water quality. The results showed that bacterial counts showed the trend of winter $<$ spring $<$ autumn < summer, indicating that the number of cultivable bacteria fluctuated with the seasons (Fig.1). The total number of 36 different genera were selected (Fig.2, Fig.3). Pseudomona sp., Azatobacter sp. and Xanthobacter sp. were the common genera in two sample sites by Origin 8 , and the three genera were dominant bacteria in D1 and D2. It also can be seen that Aerococcus sp., Rahnella sp., Klebsiella sp., Exiguobacterium sp., Ochrobactrum sp., Acidomonas sp., Arthrobacter $s p$. and Aeromicrobium sp. were specific genera in D1. Neisseria sp., Methylococcus sp. and Halobacterium were specific genera in D2.

The microbial community structure will change with the water quality [11]. The difference geographical location will leads to the different chemical composition of the water, and it will also affects the bacterial community structure. It is consistent with the results of this study. According to RDA analysis. $\mathrm{NO}_{3}^{-}$had a positive effect on Pseudomona sp. and Paracoccus sp., maybe Pseudomonas sp. and Paracoccus $s p$. were a kind of identifying bacteria, which could change $\mathrm{NO}_{3}{ }^{-}$ to $\mathrm{NO}_{2}{ }^{-}$in aerobic condition [12]. Positive correlations were found between Staphylococcus sp. and $\mathrm{NO}_{2}{ }^{-}$. Methylococcus $s p$. and Acinetobacter $s p$. had positive correlations with TN. On the contrary, Aeromonas sp., Zoogloea sp., Shigella sp., Flavobacterium sp. and Deinococcus sp. had negative correlations with $\mathrm{NH}_{3}-\mathrm{N}$.

\section{Acknowledgements}

This work supported by Integration and Demonstration of Urban Water Pollution Process Control and Comprehensive Improvement of Water Environment of National Major Science and Technology Program-water Body Pollution Control and Remediation (NO.2012ZX07301-001).

\section{References}

[1] Circular of the General Office of the State Council on Approving the Master Plan of Changzhou City. The Central People 's Government of the People' s Republic of China. (2013).

[2] J. Zou, L.F. Liu, Y.P. Tian, X.L. Xie. Study on vulnerability of surface water resources and its evaluation [J]. Resources Science. 1(2007), p. 92-98.

[3] Z.H. Li. Natural water body biofilm extracellular polymer separation method [D]. Jilin University. (2002).

[4] N.N. Yin. Liaohekou wetland microbial ecological distribution and influencing factors [D]. China Ocean University. (2011).

[5] E.H. Lilian, H.L. Alan. Microorg anisms function form and environment (2nd ed.). London Bulter \& Tanner Ltd. (1979), p. 262-274.

[6] Starzecka, Aleksandra. Bacteria Characteristics of water in the Nita River and its tributaries Acta. Hydrobiology. 4(1997), p. 341-360.

[7] C.H. Jiang, M.L. Zhang, Y.J. Tao, N. Yu, L.Q. Chen.Study on community structure of planktonic bacteria in different water quality in Shanghai [J]. Microbiology. 4(2009), p. 522-527.

[8] M. Kaevka, P. Videnska, P. Vasickova. Changes in Microbial Composition of Wastewater During Treatment in a Full-Scale Plant [J]. Current Microbiol. 72(2016), p. 128-132.

[9] T. Tu, L. Li, G.Y. Mao, Y.Y. Wang. Using Cell Counting Method and DGGE Technique to Analyze Bacterial Population Diversity in Some Areas of Songhua River Mainstream [J]. Acta 
Ecologica Sinica. 11(2012), p. 3505-3515.

[10] X. Gong, J.H. Wang, J.F. Guan, X.C. Yang, D.C. Chen. Effects of reclaimed water irrigation on soil chemical properties and cultivable microbes [J]. Environmental Science. 9(2014), p. 3572-3579.

[11] X.S. Su, X.F. Meng, W.J. Zhang, X.F. Shi, H.Y. He. Changes of microbial community in groundwater during artificial recharge[J]. Journal of Jilin University (Earth Science Edition). 2(2015), p. 573-583.

[12] Y.Y. Xu. Study on the Effect of Inoculating Bacteria on Nitrification and Denitrifying Bacteria Community of Dung Manure [D]. Northeast Agricultural University. (2015). 